慶應義塾大学学術情報リポジトリ

Keio Associated Repository of Academic resouces

\begin{tabular}{|c|l|}
\hline Title & Determination of radon-220 and radon-222 concentrations in fumarolic gases \\
\hline Sub Title & \\
\hline Author & $\begin{array}{l}\text { 山下, 京子(Yamashita, Kyoko) } \\
\text { 吉川, 英樹(Yoshikawa, Hideki) } \\
\text { 矢永, 誠人(Yanaga, Makoto) } \\
\text { 遠藤, 和豊(Endo, Kazutoyo) } \\
\text { 中原, 弘道(Nakahara, Hiromichi) }\end{array}$ \\
\hline Publisher & 共立薬科大学 \\
\hline Publication year & 1987 \\
\hline Jtitle & $\begin{array}{l}\text { 共立薬科大学研究年報 (The annual report of the Kyoritsu College of } \\
\text { Pharmacy). No.32 (1987.),p.88- 89 }\end{array}$ \\
\hline JaLC DOI & \\
\hline Abstract & \\
\hline Notes & 抄録 \\
\hline Genre & Technical Report \\
\hline URL & https://koara.lib.keio.ac.jp/xoonips/modules/xoonips/detail.php?koara_id=AN00062898-0000003 \\
2-0088
\end{tabular}

慶應義塾大学学術情報リポジトリ(KOARA)に掲載されているコンテンツの著作権は、それぞれの著作者、学会または出版社/発行者に帰属し、その権利は著作権法によって 保護されています。引用にあたっては、著作権法を遵守してご利用ください。

The copyrights of content available on the KeiO Associated Repository of Academic resources (KOARA) belong to the respective authors, academic societies, or publishers/issuers, and these rights are protected by the Japanese Copyright Act. When quoting the content, please follow the Japanese copyright act. 


\title{
Determination of Radon-220 and Radon-222 Concentrations in Fumarolic Gases*
}

\author{
Kyouko Yamashita**, Hideki Yoshikawa, Makoto Yanaga**, \\ Kazutoyo Endo** and Hiromichi NaKahara** \\ 山下京子**, 吉川英樹, 矢永誠人**, 遠藤和豊 ${ }^{* *}$, 中原弘道 ${ }^{* *}$
}

The Rn-222 concentrations in the soil gas, fumarolic gas, atmosphere, and in the underground water have been measured extensively for the studies of seismology, uranium mining, environmental science and geochemistry. It has been known that its concentrations are often very high in fumarolic gases and in the underground water, the reason for which is, however, not clarified yet.

$\mathrm{Rn}-220$ is another isotope of radon and belongs to the thorium decay series. Due to its short half life of $55.6 \mathrm{~s}$, reports on its concentrations in those gases and in natural water are still scant. They are also important for a better estimate of our exposure to natural radioactivity and also for the geochemical study of the formation of those radon isotopes and their underground movement.

In the previous paper (Yoshikawa et al., 1986), we proposed a method for the direct determination of $\mathrm{Rn}-220$ and $\mathrm{Rn}-222$ in fumarolic gases.

In the present work, an indirect method for the determination of $\mathrm{Rn}-220$ in fumarolic gases has been studied that measures essentially the activity of $\mathrm{Pb}-212$, the progeny of $\mathrm{Rn}-220$, together with a further investigation on $\mathrm{Rn}-220$ and $\mathrm{Rn}-222$ concentrations at various sites. An attempt is also made for understanding of the Rn-220 and Rn-222 data, namely, the formation and transport of the radon gas underground.

An advantage of this method is that the gas sampling does not have to be carried out fast. Thus the gas volume can be made large so long as the condensed water as well as the non-condensing gas is collected into a sampling bottle quickly. Moreover, the radioactivity measurement does not have to be performed at the sampling site. However, the disadvantage is the decreased sensitivity in the activity measurement due to the longer half life of $\mathrm{Pb}-212$, i.e., the half life of $10.64 \mathrm{hr}$ is about 690 times larger than that of $\mathrm{Rn}-220$. The measurement of $\mathrm{Pb}-212$ actually has a meaning somewhat different from the direct measurement of $\mathrm{Rn}-220$, and it is expected to give some information on the amount of Rn-220 initially drifted from the source into the up-stream of the gas if the decay products of $\mathrm{Rn}-220$ stay in the gas stream and come up to the surface.

* 本報告は ACS SYMPOSIUM SERIES No. 331. Radon and Its Decay Products: Occurrence, Properties, and Health Effects, Philip K. Hopke, Editor, 1987, American Chemical Society に発表.

** 都立大学理学部 
In the present work, lead isotopes were chemically separated from the sample gas as lead sulfide since the formation of lead sulfide was inevitable under the presence of $\mathrm{H}_{2} \mathrm{~S}$ in the fumarolic gas. The lead sulfide was then dissolved in a small amount of concentrated $\mathrm{HCl}$ and mixed with the lnsta Gel (emulsion scintillator solution, lnsta Gel, Packard inc.) for the liquid scintillation counting. The chemical yield and the volume of the collected non-condensing gas were obtained from the measurement of the activities of $\mathrm{Pb}-214$ and its progeny which were in radioequilibrium with their precursor $\mathrm{Rn}-222$ whose concentration was determined separately by the direct method.

Comparison of the direct and indirect method

\begin{tabular}{|c|c|c|c|c|}
\hline \multirow{2}{*}{\multicolumn{2}{|c|}{ Location }} & \multicolumn{2}{|c|}{ TAMAGAWA HOT SPRING } & \multirow{2}{*}{$\frac{\text { HAKONE HOT SRING }}{\text { Goemon-Jigoku }}$} \\
\hline & & Ohbuki & Higashimori & \\
\hline \multicolumn{2}{|c|}{ Temperature $\left({ }^{\circ} \mathrm{C}\right)$} & 96 & 97 & 84 \\
\hline \multicolumn{2}{|c|}{ Gas collection method } & $\begin{array}{c}\text { orifice of } \\
\text { hot spring }\end{array}$ & gas vent & $\begin{array}{l}\text { orifice of } \\
\text { hot spring }\end{array}$ \\
\hline \multirow{4}{*}{$\begin{array}{l}\text { Direct } \\
\text { Method }\end{array}$} & Sampling time (s) & 79 & $135 \sim 140$ & $4 \sim 8$ \\
\hline & $\mathrm{Rn}-222(\mathrm{kBq} / \mathrm{l})$ & $0.048 \pm 0.003$ & $0.085 \pm 0.003$ & $0.066 \pm 0.003$ \\
\hline & $\mathrm{Rn}-220(\mathrm{kBq} / \mathrm{l})$ & $5.6 \pm 0.4$ & $\begin{array}{l}1.4 \pm 0.4 \\
1.1 \pm 0.2\end{array}$ & $\begin{array}{l}0.03 \pm 0.07 \\
0.06 \pm 0.04 \\
0.09 \pm 0.03 \\
0.05 \pm 0.07\end{array}$ \\
\hline & $R n-220 / R n-222$ & $115 \pm 12$ & $\begin{array}{l}16 \pm 4 \\
13 \pm 3\end{array}$ & $\begin{array}{l}0.5 \pm 1.1 \\
0.9 \pm 0.6 \\
1.3 \pm 0.5 \\
0.8 \pm 1.1\end{array}$ \\
\hline \multirow{2}{*}{$\begin{array}{l}\text { Indirect } \\
\text { Method }\end{array}$} & $R n-220 / R n-222$ & $136 \pm 13$ & $\begin{array}{r}11 \pm 1 \\
9 \pm 1 \\
11 \pm 1\end{array}$ & $\begin{array}{l}1.5 \pm 0.3 \\
2.0 \pm 0.3\end{array}$ \\
\hline & $\mathrm{Rn}-220(\mathrm{kBq} / \mathrm{l})$ & $65 . \pm 0.7$ & $\begin{array}{l}0.93 \pm 0.07 \\
0.78 \pm 0.07 \\
0.93 \pm 0.07\end{array}$ & $\begin{array}{l}0.10 \pm 0.02 \\
0.13 \pm 0.02\end{array}$ \\
\hline
\end{tabular}

